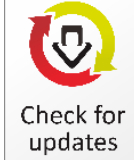

updates

Article Type: Research Paper

\title{
Highlighting Earnings Management from Islam Perspective
}

\author{
Rediyanto Putra* ${ }^{1}$ and Inneke Putri Widyani ${ }^{2}$
}

\section{OPEN}

\section{AFFILIATION:}

${ }^{1}$ Department of Accounting, Universitas Negeri Surabaya, Indonesia

${ }^{2}$ Department of Accounting, Universitas Terbuka, Indonesia

\section{*CORRESPONDENCE:}

rediputra.rp@gmail.com

THIS ARTICLE IS AVALILABLE IN:

http://journal.umy.ac.id/index.php/ai

DOI: 10.18196/jai.2003127

\section{CITATION:}

Putra, R., \& Widyani, I.P. (2019). Highlighting Earnings management from Islam Perspective. Journal of Accounting and Investment, 20(3), 251-266.

\section{ARTICLE HISTORY}

Received:

14 September 2018

\section{Reviewed:}

1 December 2018

\section{Revised:}

29 December 2018

\section{Accepted:}

10 July 2019

\begin{abstract}
This study aims to assess the behaviour of earnings management from an Islamic perspective. The form of this research is descriptive qualitative research using Islamic paradigm to make ethical judgments of earnings management actions. The analytical method used in this study is divided into two, namely descriptive and content analysis. This study concludes that basically the existing earnings management in conventional accounting is not in accordance with Islamic values. Earnings management is an act of dhazalim, contrary to the value of honesty (siddiq), contrary to itsar value, and contrary to kosher (halal thayyiban). This study also concluded that managers can create good performance with expected profit pattern based on professionalism value in accordance with Islamic shariah (akhlakul karimah) in order to be in accordance with Islamic sharia principles.
\end{abstract}

Keywords: Earnings Management; Islamic Values; Postmodern Critical

\section{Introduction}

Earnings management (EM) is an action performed by a company manager for the purpose of managing the amount of profit to be reported on a financial statement for a particular purpose. Scott (2015: 445) explains that earnings management is a form of a selection of accounting policies that impact on reported earnings with a view to achieving the specific objectives of earnings reporting. Earnings management actions can occur because of conflicts of interest that occur in agency relationships between managers and shareholders. As an agent, managers are morally responsible for optimizing the benefits of the principal, but on the other hand, managers also have an interest in maximizing their welfare. So it is likely that agents do not always act in the best interests of the principal (Jensen \& Meckling, 1976).

Managers can take earnings management actions because managers know more internal information and prospects of the company in the future than the owner (shareholders). Therefore, the manager is obliged to give a signal about the condition of the company to the owner. The signal given can be done through the disclosure of accounting information such as financial statements. However, the information submitted is sometimes received not in accordance with the actual company 
conditions. This condition is known as asymmetric information or asymmetric information. Information asymmetry occurs because managers are superior in mastering information over other parties (shareholders).

Managers carry out earnings management actions also due to the existence of opportunistic traits which are human nature. Eisenhardt (1989) states that agency theory uses three assumptions of human nature, namely (1) humans in general selfishness (selfinterest), (2) human beings have limited thinking about the bounded rationality, and (3) humans always avoid risk (risk-averse). Based on the assumptions of human nature, managers as human beings will act opportunistically by making earnings management to prioritize personal interests.

The phenomenon of earnings management that occurs in agency relations often leads to long and complicated debates. Several previous studies have sought to seek answers to the debates that have occurred regarding earnings management from a conventional point of view. Research results from Watts and Zimmerman (1986), Holthausen, Larke, and Sloan (1995), Subramanyam (1996), Davis-Friday and Frecka (2002), and Diana and Madalina (2007) suggest that earnings management is ethical and is still within the limits allowed by accounting standards. However, Healy and Wahlen (1999), Rosner (2003), Rahman and Ali (2006), Kamel and Elbanna (2009) stated that earnings management is included in the fraud of unethical financial and behavioural statements. Some of these previous studies also sought to answer the debates that occurred related to earnings management from an Islamic point of view. Hafni (2012), Marzuqi and Latif (2010), and Muliasari and Dianati (2014) have conducted research to assess earnings management from an Islamic / shariah point of view. The result of the research from Hafni (2012) states that the practice of earnings management is not contradicting the ethical principles of sharia consisting of fairness, ethics, honesty, social responsibility, and truth. However, the results of research by Marzuqi and Latif (2014) and Muliasari and Dianati (2014) explain that earnings management is against Islamic ethics.

The existence of debate related to the ethical assessment of the earnings management resulted in the form of a search for a new form of earnings management that is more ethical. The results of Zuhdi (2007) and Syaiful (2017) attempt to provide a new form of earnings management that can conform to Islamic business ethics. Zuhdi (2007) explains that the presentation of profit when reporting accounting information should prioritize the value of zakat so that the information presented will be honest, fair and correct. Meanwhile, the results of research from Syaiful (2017) states that earnings management must be in accordance with the five axioms of Islamic ethical philosophy that is unity, balance, will, responsibility, and virtue ihsan.

The explanation in the previous two paragraphs shows that earnings management is interesting to discuss in more depth. This is because until now there is often a debate related to an ethical assessment of the action of earnings management. The debate has so far not yet found a bright spot either from the conventional side or from the Islamic point of view. Therefore, this study will conduct a critical study of the ethical assessment of earnings management from an Islamic point of view. 
This study prefers to use ethical judgment from an Islamic point of view for two reasons: (1) research related to ethical judgment related to earnings management by using Islamic point of view is rarely done and (2) the point of view of Islamic value has added value because ethical judgment is done by using guidelines of Muslim life that is AlQur'an and Al-Hadith. This corresponds to Q.S. An-Nisa 'paragraph 59 as follows:

\footnotetext{
"O you who have believed, obey Allah and obey the Messenger and those in authority among you. And if you disagree over anything, refer it to Allah and the Messenger, if you should believe in Allah and the Last Day. That is the best [way] and best in the result." (Q. S. al-Nisa': 59)
}

This study is based on research results from Syaiful (2017) and Marzuqi and Latif (2014). Thus, the formulation of the problem to be answered in this study is as follows:

1. Is earnings management consistent with the Islamic principles contained in the Qur'an and Al-Hadith?

2. How to make earnings management can be in accordance with Islamic values contained in Al-Qur'an and Al-Hadith?

The results of this study are expected to contribute in the form of suggestions and inputs related to the ethical assessment of earnings management. In addition, the results of this study are expected to generate a new form of earnings management in accordance with Islamic principles.

\section{Literature Review}

\section{Earnings management}

Earnings management (EM) is a method undertaken by the company manager to manage the amount of profit reported in the company's financial statements in order to achieve certain goals. Scott (2015: 445) defines earnings management as an election of accounting policies or actions that have an impact on earnings in order to achieve some of the specific objectives of the profit reporting. Furthermore, Healy and Wahlen (1999) stated that earnings management occurs when managers use judgment in financial reporting which aims to mislead stakeholders about the company's main economic performance in order to influence contractual results based on accounting figures reported. Based on both definitions can be concluded that earnings management can be done by the manager because it has the power in the selection of accounting methods that can have an impact on the performance of the company submitted on the company's financial statements.

Earnings management conducted by corporate managers can be understood from two different angles. Scott (2015: 448-457) states that earnings management can be seen from two perspectives, namely opportunistic behaviour and efficient contracting. The 
first point of view of earnings management is the opportunistic behavior of managers. Earnings management is seen as a manager behavior that aims to maximize self-utility when faced with contract compensation, debt contract and political cost (opportunistic earnings management). The second point of view of earnings management is the efficient contract perspective. This manager's earnings management is seen as an act to protect managers and managers in the face of unforeseen and incomplete and difficult to fulfil for the benefit of the parties involved in the contract.

Earnings management in companies can occur because of some motivation that comes from human nature. Motivation earnings management conducted by the company's managers basically cannot be separated from the agency relationship between managers with investors, managers with creditors, and managers with the government. Watts and Zimmerman (1986) and Scott (2015: 448-457) explain some of the things that can be motivated by the actions of earnings management by managers, among others:

\section{a. Bonus Scheme}

Companies that plan to give bonuses to managers with good performance will make the chance of earnings management is greater. Company managers will use more accounting methods that can shift future earnings into current profits. The purpose of profit spin by using the accounting method is so that profit can be above bogey (lowest profit level) and under stamp (highest profit rate). This is done because if the profit is under bogey then the manager will not get a bonus, whereas if the profit is above the cap then the manager will not get additional bonus.

b. Debt Covenant

Companies that have a high Debt to Equity Ratio, then managers will be more likely to choose accounting methods that can increase revenue or profit companies. This is done by the manager on the grounds that the company does not have difficulty in obtaining additional funds from the creditors that can cause companies threatened to violate the debt agreement.

c. Political Cost

Companies that have large sizes will have higher political costs, therefore managers will tend to use accounting methods that can suspend profits reported in the current period to the period that will come. This is done in order to minimize reported profits, so the political cost becomes small.

\section{d. Taxation Motivation}

Taxation is a thing that can reduce the level of profit obtained by the company, therefore managers make earnings management to reduce the amount of reported earnings. It aims to reduce the amount of tax payable by the company.

e. Change of CEO

CEOs who will enter retirement or expiration of the contract will then do a strategy to maximize the amount of reported profit in order to obtain a higher bonus amount. 
The same thing is done by the manager who had a poor performance from being fired (De Angelo, 1988; Pourciau, 1993).

f. Initial Public Offering (IPO)

Companies that conduct Initial Public Offering (IPO) tend to perform earnings management actions to provide good information about the company's performance. Such information is important because it can be a signal to potential investors regarding the value of the company.

Based on some of the motivations of Watts and Zimmerman (1986) and Scott (2015: 448-457) implies that the earnings management performed by managers is due to agency relationships with investors, managers with creditors, and managers with government. The agency's relationship ultimately leads managers to earn earnings management in order to protect their own and the company's interests when unexpected events occur.

Earnings management by managers can be done by using accounting methods tailored to the objectives to be achieved. Thus, the earnings management conducted by the company's management must have different ways and patterns that fit the goals to be achieved. Naim and Hartanto (1996) explained that there are three ways in which managers make earnings management (1) take advantage of opportunities for accounting estimates, (2) change accounting methods, and (3) shift the cost or income period. The way that managers do to perform the action earnings management is then adjusted to the goals to be achieved by managers so that eventually will bring the pattern of action earnings management. Scott (2015: 447) describes some of the patterns of earnings management actions that include:

a. Taking a Bath

This pattern of earnings management often occurs when the appointment of a new CEO within the company. The pattern of earnings management is done by reporting large losses with the aim that in the future period can report an increased profit.

b. Income Minimization

The earnings management pattern is performed when the company earns a high amount of profit, so managers make this earnings management pattern to reduce the amount of earnings reported. This is done with the aim to anticipate if in the next period earnings will decrease drastically.

c. Income Maximization

The pattern of earnings management is done when the company experienced a decrease in the amount of profits earned, so managers make earnings management of this pattern to increase the amount of reported profit. The purpose of this earnings management pattern is to avoid breach of debt agreement. 
Putra \& Widyani

Highlighting Earning Management from Islam Perspective

d. Income Smoothing

The pattern of earnings management is done by levelling the amount of profit reported by the company. This is because in general investors prefer companies that have stable profit fluctuations.

\section{Previous Research}

Research related to the ethical assessment of previous earnings management has been done. The explanation of prior research in this study is used as a basis for strengthening the justification made. The previous research used in this research are as follows:

Table 1 Previous Research

\begin{tabular}{|c|c|c|}
\hline Name & Method & Result \\
\hline Zuhdi (2007) & $\begin{array}{l}\text { This study uses a postmodern } \\
\text { approach to understanding and } \\
\text { interpretation }\end{array}$ & $\begin{array}{l}\text { The results of this study indicate that the } \\
\text { profit concept of sharia accounting is } \\
\text { used as a basis for performing } \\
\text { performance appraisal from } \\
\text { management to perform resource } \\
\text { management to present profit with } \\
\text { zakat oriented }\end{array}$ \\
\hline $\begin{array}{l}\text { Marzuqi \& Latif } \\
(2010)\end{array}$ & $\begin{array}{l}\text { This study uses a descriptive } \\
\text { reference study method that } \\
\text { refers to the reference related } \\
\text { to Islam, Islamic business, and } \\
\text { earnings management. }\end{array}$ & $\begin{array}{l}\text { The results show that earnings } \\
\text { management has not been compatible } \\
\text { with the teachings of Islam. Earnings } \\
\text { management should be done through } \\
\text { good operations management }\end{array}$ \\
\hline Hafni (2012) & $\begin{array}{l}\text { This research uses qualitative } \\
\text { research with descriptive }\end{array}$ & $\begin{array}{l}\text { The results of this study indicate that } \\
\text { shariah ethics has a view that earnings } \\
\text { management is an ethical behaviour } \\
\text { when not contrary to the principles of } \\
\text { sharia ethics that is fairness, ethics, } \\
\text { honesty, social responsibility and Truth. }\end{array}$ \\
\hline $\begin{array}{l}\text { Muliasari \& } \\
\text { Dianati (2014) }\end{array}$ & $\begin{array}{l}\text { This study uses qualitative } \\
\text { descriptive through the } \\
\text { exposure of actual information } \\
\text { in the form of words, images of } \\
\text { literature study activities. This } \\
\text { study also conducted } \\
\text { interviews related to earnings } \\
\text { management, Islamic business } \\
\text { ethics }\end{array}$ & $\begin{array}{l}\text { The results showed that earnings } \\
\text { management is not in accordance with } \\
\text { Islamic business ethics. Islamic business } \\
\text { ethics contains the values of tauhid, } \\
\text { unity; fair, equilibrium; freedom; } \\
\text { responsibility; ihsan, benevolence. }\end{array}$ \\
\hline Syaiful (2017) & $\begin{array}{l}\text { This research is conducted } \\
\text { using a qualitative research } \\
\text { method with critical approach. }\end{array}$ & $\begin{array}{l}\text { The results show that earnings } \\
\text { management on Islamic ethics should } \\
\text { consider the related processes, impacts, } \\
\text { and implications of the conduct of } \\
\text { earnings management }\end{array}$ \\
\hline
\end{tabular}


Putra \& Widyani

Highlighting Earning Management from Islam Perspective

\section{Research Method}

The form of this research is descriptive qualitative research using Islamic paradigm to make ethical judgments of earnings management actions. The Islamic paradigm means that the basis used in building science is Islamic aqeedah not understanding secularism (IImi, 2012). Thus, the Islamic paradigm is a paradigm that is used to build a concept that does not conflict with Islamic Aqeedah namely Al-Qur'an and Al-Hadith. The use of the Islamic paradigm is expected to be able to answer the existence of problems related to the long debate from the ethical assessment of earnings management actions. This is because in this study the ethical assessment of earnings management actions is directly based on Muslim sources of life guidance, namely the Qur'an and Al-Hadith. In addition, the use of the Islamic paradigm in research can also overhaul and create the concept of earnings management that can be in accordance with Islamic Aqeedah.

The data needed in this study are in accordance with the objectives and the research method used is qualitative textual data. Therefore, the data collection technique in this study uses the library research method. The primary data in this study are data originating from the Qur'an and Al-Hadith, while the secondary data used in this study is data derived from library materials such as books, magazines, journals, articles, and others that are related with earnings management. The analytical method used in this study is divided into two, namely descriptive and content analysis. The descriptive method in this research is to collect and compile a data, then make an explanation related to the data obtained as is to get information about the problem under study. Furthermore, content analysis in this study will be carried out through the analysis of the contents of the data that has been described descriptively in accordance with the boundaries of the related problems.

\section{Result and Discussion}

\section{Earnings management and Misleading Information from an Islamic Perspective}

Earnings management by corporate managers can lead to misleading information for users of financial statements. Healy and Wahlen (1999) stated that earnings management in financial reporting aims to mislead the stakeholders regarding the main economic performance of the company in order to influence the contractual results based on accounting figures reported. The existence of earnings management actions performed on the company's financial statements cause the accounting information presented to be not in accordance with the actual reality. This, in turn, will make the users of financial statements to be wrong in decision making. Thus, it can be misleading and harmful to users of financial statements.

The existence of the negative consequences of earnings management is misleading information, so this makes the earnings management action is not in accordance with Islamic values. This is in accordance with the word of Allah contained in the letter of the Qur'an 49. Al Hujuraat paragraph 6 as follows: 
"O you who have believed, do not put [yourselves] before Allah and His Messenger but
fear Allah. Indeed, Allah is Hearing and Knowing." (Q.S Al Hujuraat:6)

The Word of Allah SWT clearly states that the people who bring the news that can bring disaster or problems are the people who are ungodly. Thus, any manager who performs earnings management actions also belongs to a group of people who are ungodly. The wicked nature is a character that denies the teachings of Allah SWT under the prophets (Syawal, 2016). Therefore, the act of earnings management is obliged to be abandoned so as not to fall into the group of the wicked.

Earnings management actions that provide misleading information to users of financial statements will result in losses. Thus, corporate managers have committed malicious actions (dzalim) to users of financial statements only to achieve the desired goals. Based on that, then the act of earnings management is required to be shunned because Allah SWT has said in Surah Al-An'am verse 160 as follows:

"Whoever comes [on the Day of Judgement] with a good deed will have ten times the like thereof [to his credit], and whoever comes with an evil deed will not be recompensed except the like thereof, and they will not be wronged." (Q.S. AlAn'am:160)

The Word of Allah SWT in Surah Al-An'am verse 160 clearly states that any good or bad deeds done will earn a worthy reply. In other words, the act of earnings management that has hurt the users of financial statements will also get a balanced reply.

The explanation of the two verses of the Qur'an shows that the actual act of earnings management by managers is not in accordance with Islamic values. Earnings management by managers is clear evidence of misleading information for users of financial statements for the achievement of specific goals. Thus, the act of earnings management should be avoided so as not to fall into the group of the wicked and get vengeance from Allah SWT for crimes (dzalim) to the users of financial statements. Figure 1 shows the form of incompatibility of earnings management measures with Islamic values regarding misleading information.

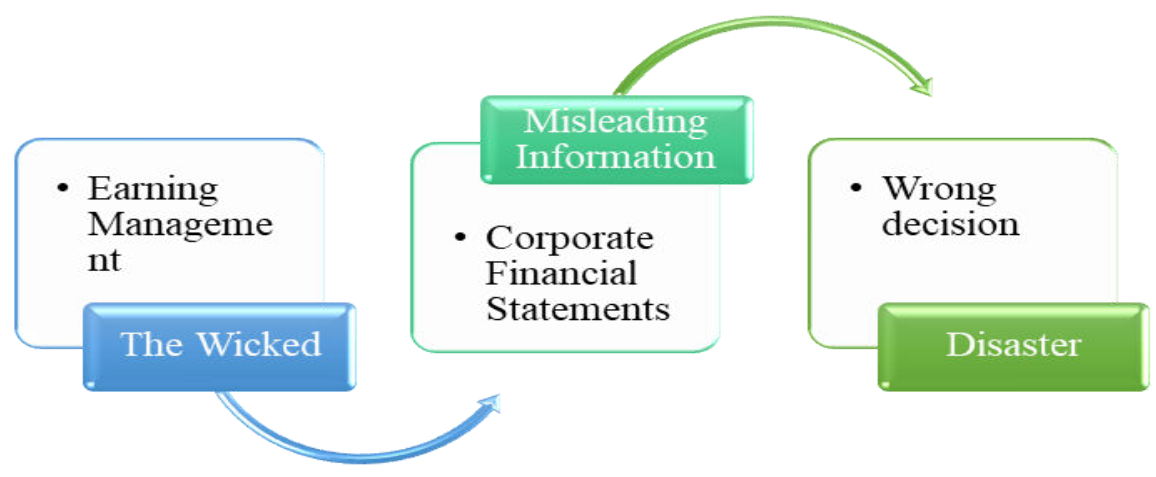

Figure 1 Earnings management and Misleading Information 
Putra \& Widyani

Highlighting Earning Management from Islam Perspective

\section{Earnings management and Honesty Values (Siddiq)}

The explanation in the previous section states that earnings management by managers seeks to provide misleading information to stakeholders. This concludes that earnings management has also neglected the values of honesty (siddiq). The accounting methods used by managers to change the earnings information reported in the financial statements have attempted to change the actual performance conditions of the firm to the conditions that are in line with the manager's objectives. In other words, managers have provided lying information to stakeholders. This is clearly incompatible with the principles of Islam because people who always behave dishonestly are included in the characteristics of the hypocrites as contained in the following hadith:

"If he speaks then he lies, if promised he denied, if given the trust then he betrayed". (HR Al Bukhari)

Hadith narrated Al Bukhari explains that people who lie or dishonest is included to the hypocrites. Thus, parties who intentionally make earnings management with the aim to change the information on the condition of the company's performance from the real to be in accordance with the desired goals through accounting methods are included to the hypocrite. Such parties will inevitably at some point do more harm to the stakeholder such as treason and other frauds. This is because the party who makes earnings management is including those who are hypocritical with the properties of liars, promises, and traitors. Therefore, earnings management behaviour as early as possible should be avoided in order to avoid the nature of the hypocrites.

The behaviour of earnings management also need to be avoided as early as possible to avoid the nature of the hypocrites because the hypocrites included in the class of disbelievers who are hated by Allah SWT. This is as mentioned in the word of Allah SWT on Surah An-Nisa 'verses 144-147 as follows:

"O you who have believed, do not take the disbelievers as allies instead of the believers. Do you wish to give Allah against yourselves a clear case? Indeed, the hypocrites will be in the lowest depths of the Fire - and never will you find for them a helper. Except for those who repent, correct themselves, hold fast to Allah, and are sincere in their religion for Allah, for those will be with the believers. And Allah is going to give the believers a great reward. What would Allah do with your punishment if you are grateful and believe? And ever is Allah Appreciative and Knowing. (Q.S An-Nisa': 144-147).

The previous verse shows that every hypocrite will be placed by Allah SWT into hell. This shows that Allah SWT hates the hypocrites very much. Thus, the behaviour of earnings management which is the embryo of the emergence of the nature of the characteristics of a hypocrite must be avoided from the beginning. Figure 2 shows the form of nonconformance to earnings management measures with honesty value in Islam. 




Figure 2 Non-compliance Earnings management and Honesty Value (Siddiq)

Actions earnings management conducted by managers can trigger the emergence of the nature of the hypocritical person due to a lack of gratitude to Allah SWT. Syaiful (2017) explains that one of the goals of earnings management is utility maximization. This shows that managers earn earnings management earnings due to the lack of satisfaction of what has been obtained from the activities of the company. In addition, managers are also not satisfied with the earnings received and want more bonus if the company managed to have satisfactory performance. Thus, managers make an earnings management effort to maximize utility. Managers forget that the act of earnings management done has neglected the values of honesty and resulted in the nature of the hypocrites.

Actions earnings management conducted by managers can also trigger the emergence of the nature of the hypocritical person due to lack of faith in Allah SWT. Scott (2015) states that earnings management is based on reasons to protect themselves by managers to deal with unexpected and incomplete conditions and difficulties in fulfilling contracts. It shows that actually manager's action has a belief that everything that happens to man has been arranged by Allah SWT. Managers should believe and believe that all affairs possessed are the will of Allah SWT and always ask for guidance to Allah SWT when experiencing difficulties over unforeseen events/conditions. This is in accordance with the word of Allah in verse 86 of Surah Yusuf verse 86 and Al Baqarah verse 186 as follows:

"He said, "I only complain of my suffering and my grief to Allah, and I know from Allah that which you do not know." (QS Yusuf: 86)

"He said, "I only complain of my suffering and my grief to Allah, and I know from Allah that which you do not know." (QS Al Baqarah: 186)

Both verses previous explain that Allah SWT always helps and grant every request of His servant. Thus, managers do not have to worry and be afraid of all kinds of unexpected conditions or difficult conditions to achieve from contracts that have been made. Managers also do not need to make an earnings management action that neglects honesty in the delivery of accounting earnings information to stakeholders, so included in the characteristics of people who are hypocritical. 
Putra \& Widyani

Highlighting Earning Management from Islam Perspective

\section{Earnings management and Itsar Characteristics}

Earnings management by managers basically only aims to meet personal interests regardless of the interests of others. Watts and Zimmerman (1986) and Scott (2015: 448-457) explain that earnings management is based on several motivations: bonus scheme, debt covenant, political cost, taxation motivation, CEO turnover, Initial Public Offering (IPO). The six earnings management motivations show that many external parties / other parties whose interests are neglected by managers due to earnings management. The motivation of bonus schemes and CEO turnover is a motivation that focuses on maximizing the manager's personal utility and abandoning the interests of others, especially shareholders. Furthermore, the motivation of debt covenants is the motivation of earnings management that ignores the interests of parties who provide debt to the company. Finally, the motivation of political cost and taxation motivation and Initial Public Offering (IPO) is the motivation of earnings management that neglects interests such as government and society.

Earnings management actions that do not care about the interests and only prioritize personal interests are not in accordance with Islamic values. This is because the action of earnings management does not match the nature of itsar taught in Islam. The Word of Allah SWT in Surah Al-Hashr verse 9 describes the nature of itsar as follows:

\footnotetext{
"And [also for] those who were settled in al-Madinah and [adopted] the faith before them. They love those who emigrated to them and find not any want in their breasts of what the emigrants were given but give [them] preference over themselves, even though they are in privation. And whoever is protected from the stinginess of his soul it is those who will be successful." (Q.S. Al-Hasyr: 9).
}

The previous verse clearly indicates that itsar nature of putting other people's interests before self-interest is something that is advocated in Islam. Itsar properties must be done without expecting reward in any form (sincere).

The explanation in the preceding paragraph clearly indicates that the managers' earnings management is clearly incompatible with Islamic values. Earnings management by managers has shown the appearance of a miserly nature, so managers no longer think about the negative impact of earnings management on the interests of others. The company's managers only think about the effort that earnings management that has been done to achieve the goals that have been set.

Unacceptable earnings management action because it only emphasizes the manager's personal interests and disregards the interests of others is also presented by Mujianto who is an Investment Advisor. Mujianto in Khairani (2015) states that earnings management practices are unjustifiable and are corrupt because they are based on the fulfilment of personal interests to the exclusion of the interests of others. Thus, the act of earnings management is true if it is said to be an action that violates its nature and not in accordance with Islamic values. Figure 3 shows the form of incompatibility of earnings management action with itsar nature in Islam. 


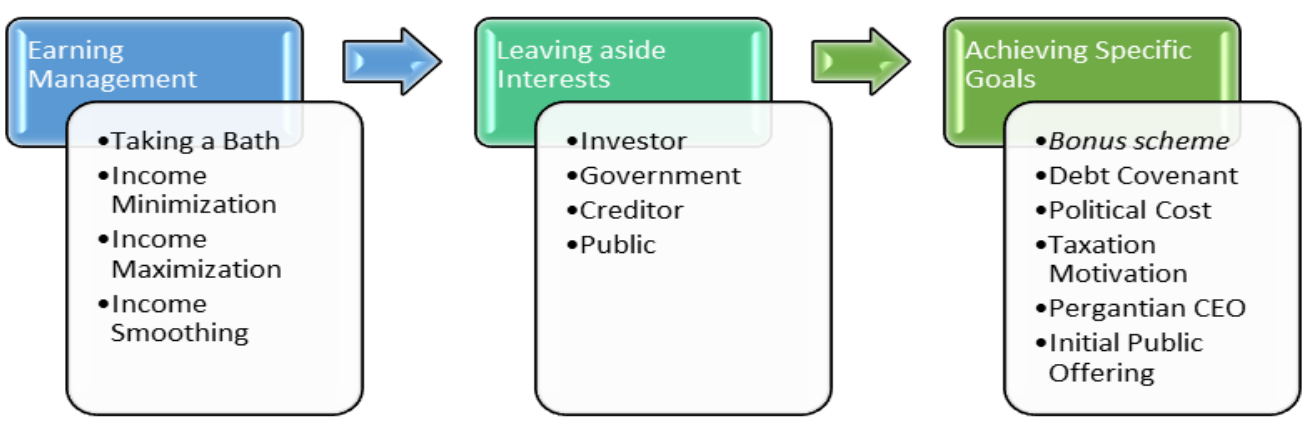

Figure 3 Non-compliance Earnings management and Itsar Characteristics

\section{Earnings management and Goodness Principle (Halalan Thayyiban)}

Earnings management is basically also against the kosher (halalan thayyiban). Earnings management conducted by managers eliminates the honesty aspect of the delivery of information that causes the users of financial statements to get misleading information, thus experiencing errors in decision making due to maximizing personal interests. Earnings management uses unlawful and good actions to achieve the desired goals for misleading others, leaving aspects of honesty, and the interests of others. Thus, earnings management by managers is not in accordance with Islamic values that is kosher (halal and thayyib).

Islam teaches that every action must be guaranteed halal and good. This is in accordance with the word of Allah in the Surah An-Nahl verse 114 as follows:

"Then eat of what Allah has provided for you [which is] lawful and good. And be grateful for the favour of Allah, if it is [indeed] Him that you worship." (Q.S. AnNahl:114)

The previous verse explains that all food eaten must come from sustenance that is lawful and grateful for the sustenance. Earnings management by managers will cause the sustenance earned from the bonus earned and / or other income earned will be unlawful. This is because the sustenance earned from the action of earnings management is the sustenance obtained through a bad road that is misleading, deceiving, and harming others. Thus, the food earned from money from earnings management is illegal food.

Earnings management by managers causes the acquired property to be illegimate (haram) and not good for life. Impact of illicit treasures conveyed in the words of Prophet Muhammad SAW conveyed in the hadith as follows:

"Whoever tries to find unlawful possessions, then if donated will not be accepted, whereas if he left it, it will add into Hell." (HR. Ahmad)

The previous hadith clearly implies that the forbidden treasure should be avoided. This is because unlawful possessions can not be sanctified in any way including alms. 
Unlawful possessions can also be a way to get to hell. Thus, the act of earnings management as an act of haram and not thayyib is supposed to be abandoned so as not to be the starting point of the road to hell. Figure 4 shows the form of incompatibility of earnings management action with the principle of thayyiban in Islam.

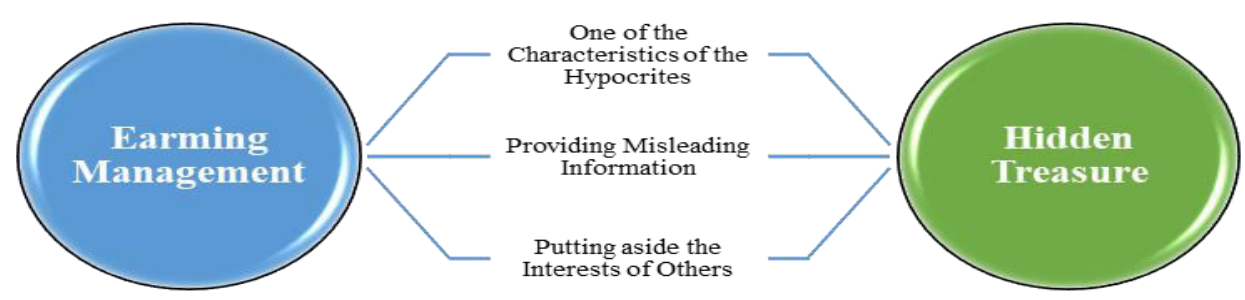

Figure 4 Non-compliance of Earnings management and Thayyiban Halal Principles

\section{Earnings management Through Akhlakul Karimah}

The explanation in the preceding sections shows that earnings management in conventional accounting is an act contrary to Islamic values. Earnings management in conventional accounting has contradicted the Islamic values and principles because it provides misleading information, is one of the characteristics of the hypocrites, overrides the interests of others, and causes unlawful property. Thus, earnings management with conventional principles is supposed to be abandoned.

Earnings management with the conventional principle is basically should be abandoned, but to make an entity can run with good performance also required a form of management of maximal profit. Therefore, earnings management in accordance with Islamic principles needs to be done. This is because the company can have a good performance but still in accordance with the values and principles of Islamic teachings.

Earnings management can basically be in accordance with Islamic values and principles by changing the form of actions taken. Earnings management can be done by doing good and professional management of the company's operational activities so that the resulting performance will be as expected. Professional principles in Islamic teachings are known as judcious (itqon). Abu Daud's historical hadith explains the professional principles as follows:

"Verily God loves someone when doing something work, done professionally (itqon)" (HR Albany).

The previous hadith conveys that Allah SWT really enjoys people who work professionally (itqon). Therefore, a manager who wants to succeed in managing a company must be done in a professional way. Managers should not use earnings management that can make accounting information biased and result in mistakes in decision making. 


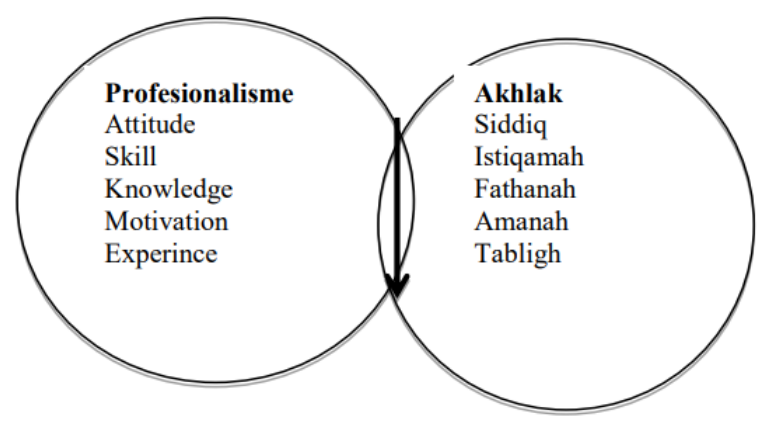

Figure 5 Professionalism and Akhlakul Karimah Source: Norvadewi (2014)

The manager can be said to be professional in Islam if he has five characteristics, namely honest (siddiq), strong conviction (istiqamah), intelligent and wise (fathanah), trustworthy (amanah), and openness (tabligh). These five properties are basically a solution for managers to not have the desire to carry out conventional earnings management actions that are not in accordance with Islamic teachings. The following figure presents the relationship between professionalism and behaviour that managers need to have to manage earnings in accordance with Islamic sharia.

Figure 5 is that if you want to achieve professionalism in accordance with Islamic Shari'ah it should seek to bring closer ties that occur between the two circles of professionalism and akhakul karimah. The closer the connection occurs, the better the performance is.

A manager who has the fifth akhlakul karimah is certainly going to conduct profit management activities that are not contrary to the teachings of Islam. Managers will not use accounting methods to provide misleading information and harming stakeholders for having siddiq, amanah, and tabligh properties. Managers can also create and manage corporate profits well because it has the nature of fathanah and istiqamah. The manager knows what decisions to take in various conditions because of his intelligence, wisdom, and stance. Thus, managers are able to produce good performance without having to change the real information by using accounting methods and misleading the stakeholders.

\section{Conclusion}

This study aims to assess the earnings management from an Islamic point of view. This study also aims to provide input on the form of earnings management that can be in accordance with Islamic perspectives. The results of previous discussions indicate that basically earnings management is an action that is contrary to Islamic values. This is because earnings management provides misleading and detrimental information to stakeholders, contrary to the values of honesty (siddiq), contrary to the value of caring (itsar), and contrary to the values of goodness (halalan thayyiban). Therefore, earnings 
management must be abandoned. Managers can create good corporate performance through expected profit management through professionalism in accordance with Islamic sharia. The manager must manage the expected earnings by having akhlakul karimah that is honest (siddiq), strong establishment (istiqama), intelligent and wise (fathanah), trustworthy (amanah), and openness (tabligh). Thus, the actions taken by managers are not against Islamic sharia and can still create good company performance.

\section{References}

Al-Qur'an Al-Karim

Davis-Friday, P., \& Frecka, T. (2002), What Managers Should Know About Earnings Management - Its Prevalence, Legality, Ethicality, and Does It Work?, Review of Accounting and Finance, 1(1), 57-71. https://doi.org/10.1108/eb026979

De Angelo, L. (1986). Accounting Numbers as Market Valuation Substitutes: A Study of Management Buyouts of Public Stockholders. The Accounting Review, 61(3), 400-420.

Diamastuti, E. (2015). Paradigma Ilmu Pengetahuan Sebuah Telaah Kritis. Jurnal Akuntansi Universitas Jember, 10(1), 61-74. https://doi.org/10.19184/jauj.v10i1.1246

Diana, B., \& Madalina, P. C. (2007). Is Creative Accounting a Form of Manipulation? Economic Science Series. Annals of the University of Oradea

Eisenhardt, K. M. (1989). Agency Theory: An Assessment and Review. The Academy of Management Review, 14(1). 57-74. https://doi.org/10.5465/amr.1989.4279003

Hafni, D. A. (2012). Praktik Earnings management dalam Perspektif Etika Syari’ah. Ekonomika-Bisnis, (3)2, 99-110. https://doi.org/10.22219/jekobisnis.v3i2.2233

Healy, P., \& Wahlen, J. (1999). A Review of Earnings Management Literature and Its Implications for Standard Setting. Accounting Horizons, 13(4), 365-383. https://doi.org/10.2308/acch.1999.13.4.365

Holthausen, R. W., Larke, K. M., Sloan, R. G. (1995). Annual Bonus Schemes and the Manipulation of Earnings. Journal of Accounting and Economics, 19(1), 29-74. https://doi.org/10.1016/0165-4101(94)00376-g

Ilmi, Z. (2012). Islam Sebagai Landasan Perkembangan llmu Pengetahuan Dan Teknologi. Jurnal Komunikasi Dan Sosial Keagamaan, XV(1), 96-106.

Jensen, M. C., \& Meckling, W. H. (1976). Theory of The Firm: Managerial Behavior, Agency Cost, and Ownership Structure. Journal of Financial Economics, 3(4), 305-360. https://doi.org/10.1016/0304-405x(76)90026-x

Kamel, H., \& Elbanna, S. (2010). Assessing The Perceptions of The Quality of Reported Earnings in Egypt. Managerial Auditing Journal, 25(1), 45. https://doi.org/10.1108/02686901011007298

Marzuqi, A. Y., \& Latif, A. B. (2010). Manajemen Laba Dalam Tinjauan Etika Bisnis Islam. Jurnal Dinamika Ekonomi \& Bisnis, 7(1), 1-22

Muliasari, I., \& Dianati, D. (2014). Manajemen Laba dalam Sudut Pandang Etika Bisnis Islam. Jurnal Akuntansi dan Kenangan Islam, 2(2), 157-182. https://doi.org/10.35836/jakis.v2i2.47

Naim, A., \& Hartono. (1996). The Effect of Antitrust Investigation on the Management of Earnings A Further Empirical Test of Political Cost Hypothesis. Kelola, 13(5), 126141.

Norvadewi. (2014). Profesionalisme Bisnis dalam Islam. $M A Z A H I B, 13(2)$, 175-188. 
Putra \& Widyani

Highlighting Earning Management from Islam Perspective

Pourciau, S. (1993). Earnings management and Nonroutine Executive Changes. Journal Accounting and Economics, 16(1-3), 317-336. https://doi.org/10.1016/01654101(93)90015-8

Rahman, A. R., \& Ali, F. H. M. (2006). Board, Audit Committee, Culture and Earnings Management: Malaysian Evidence. Managerial Auditing Journal 21(7), 783-804. https://doi.org/10.1108/02686900610680549

Rosner, R. L. (2003). Earnings Manipulation in Failing Firms. Contemporary Accounting Research, 20(2), 361-408. https://doi.org/10.1506/8evn-9krb-3ae4-ee81

Scott, W. R. (2015). Financial Accounting Theory Seventh Edition. Prentice-Hall

Subramanyam, K. (1996). The Pricing of Discretionary Accruals. Journal of Accounting and Economics, 22(2), 249-281. https://doi.org/10.1016/s0165-4101(96)00434-x

Syaiful, M. (2017). Management Laba (Earnings Management) dalam Tinjauan Etika Islam. Ekomadania, 1(1), 28-56.

Syawal, A. (2016). Sifat- Sifat Fasik dalam Al-Qur'an. Skripsi. Universitas Islam Negeri Alauddin Makassar

Watts, R. L., \& Zimmerman, J. L. (1986). Positive Accounting Theory. Prentice-Hall, Englewood Cliffs.

Zuhdi, R. (2007). Telaah Kritis atas Compensation Plan dalam Manajemen Laba (Perspektif Syari'ah). Jurnal Infestasi, 3(2), 90-127. 